\title{
LAS COFRADÍAS Y LA INTRODUCCIÓN DEL TEMPLE EN LOS REINOS DE ARAGÓN Y PAMPLONA: GUERRA, INTERESES Y PIEDAD RELIGIOSA
}

\author{
José ÁNGEL LEMA PUEYO \\ Universidad del País Vasco
}

(Vitoria)

SUMARIO

1. El espinoso problema de los orígenes.- 2. Una poderosa red de cofrades.- 3. Conclusiones y replanteamiento de un viejo problema.

La historia de las no siempre bien llamadas órdenes militares hispanas cuenta ya con una amplia bibliografía. El investigador, que desee trabajar en estas cuestiones y, sobre todo, en el estudio del Templo de Jerusalén, cuenta hoy día con útiles e insustituibles herramientas de trabajo que le pueden orientar en sus consultas. Un grupo de investigadores de la Universidad Autónoma de Madrid ha publicado un estado de la cuestión sobre las órdenes militares hispanas y una exhaustiva recopilación bibliográfica que comenta y da a conocer los estudios recientes hasta 1992'. Como no tendría sentido repetir las conclusiones de obra tan siste-

'Cf. Carlos Ayala y otros, Las Órdenes Militares en la Edad Media Peninsular: Historiografía 1976-1992. I. Reinos de Castilla y León, "Medievalismo", 2 (1992), pp. 119-169, de los mismos autores: Las Órdenes Militares en la Edad Media Peninsular: Historiografía 1976-1992. II Corona de Aragón, Navarra y Portugal, "Medievalismo", 3 (1993), pp. 87144. Orientaciones útiles para Aragón, hasta 1979, pueden hallarse en el enciclopédico trabajo de Agustín UBIETO, Historia de Aragón: Bibliografía para su estudio (Anubar ediciones, Zaragoza, 1980). También puede acudirse a las apretadas notas bibliográficas que

"Anuarıo de Estudios Medievales", 28 (1998) 
mática, a ella nos remitimos para las publicaciones anteriores a esa fecha. La producción historiográfica ha continúado, sin duda, en los últimos años. No podemos ser exhaustivos ni el espacio de que disponemos nos lo permite. Nos limitaremos a mencionar unos pocos jalones significativos. Continúa siendo necesario consultar a Gonzalo Martínez Díez para el cabal conocimiento de la historia templaria en Castilla y León ${ }^{2}$, mientras que María Luisa Ledesma Rubio ha desempeñado un papel clave para Aragón ${ }^{3}$. En Cataluña, sobresale como obra de conjunto la historia templaria de Josep Maria Sans i Travé, director del Archivo Nacional de Cataluña ${ }^{4}$.

Nuestro objetivo es mucho más concreto y limitado. Pretendemos exponer los problemas que suscita el conocimiento de los primeros pasos de la institución templaria en los reinos de Aragón y de Pamplona, en especial, bajo los últimos años del reinado de Alfonso I "el Batallador" y el papel que juegan los intereses nobiliarios en este proceso.

\section{EL ESPINOSO PROBLEMA DE LOS ORÍGENES}

Nada más difícil que rastrear los orígenes de una institución, sobre todo, si se trata de una orden religiosa medieval. Más en concreto, la llegada y primeros pasos del Templo de Jerusalén en Aragón y Navarra casi se pierden en una niebla de conjeturas y suposiciones. Si queremos abrirnos camino por ellas, la revisión de las parcas evidencias documentales, públicas y de particulares, conservadas para los últimos años de su largo reinado (1104-1134) puede ser un ejercicio útil a fin de arrojar luz sobre el problema.

publica en las tres primeras páginas de su artículo Cofrades aragoneses y navarros de la milicia del Temple (siglo XII): aspectos socio-económicos, "Aragón en la Edad Media", III (1980), pp. 29-93. Existe una recopilación general de A. DAILLIEZ, con su Bibliographie du Temple (D. L. Editeur, Paris, 1972).

'Gonzalo Martínez Díez, Los templarios en la Corona de Castilla, Editorial la Olmeda, Madrid, 1993.

${ }^{3}$ María L. Ledesma RuBio, Templarios y Hospitalarios en el Reino de Aragón, ed Guara, Zaragoza, 1982 y de la misma autora, Las órdenes militares en Aragón, Zaragoza, 1994. Para Navarra, es imprescindible el artículo de Santos García LARRAGUETA, El Temple en Navarra, "Anuario de Estudios Medievales", 11 (1981), pp. 635-661.

${ }^{4}$ Josep M. SANS I TRAVÉ, Els templers catalans: de la rosa a la creu, Pagès Editors, Barcelona, 1996. 
Algunos de estos datos plantean más incógnitas de las que resuelven. Por ejemplo, el 17 de diciembre de 1128, Alfonso I cedió a cierto particular, Miro Pedro, una iglesia situada en Gallur, dotada con inmuebles en Boquiñeni y Luceni, y otro templo más en Razazol. Una parte de estos bienes fue cedida posteriormente por D. Miro al Temple. Podría creerse que se trata del primer testimonio que prueba la existencia de los templarios en tierras aragonesas. Ahora bien, de hecho, ignoramos cuándo tuvo lugar esta segunda adquisición por los templarios, puesto que Miro Pedro se limitó a dejar constancia de su donación en la propia carta del rey, aprovechando el espacio que en los diplomas reales se dejaba para el signo del monarca, pero sin precisar fecha alguna. Evidentemente, necesitamos más datos ${ }^{5}$.

Una referencia más, igualmente difícil de interpretar, la hallamos en un documento expedido por los obispos y abades de Aragón y Pamplona, a una con el arzobispo de Auch. En la carta, se hace entusiasta propaganda de una institución similar al Temple, aunque de origen aragonés. Se trata de la cofradía militar de Monreal del Campo (prov. de Teruel). Los prelados ofrecen ventajas espirituales a los cofrades de Monreal y solicitan ayuda económica para estos combatientes. El documento contiene una mención significativa, que reproducimos: "A esto (a los privilegios de la institución) el rey añadió que esta santa milicia estuviese libre de todo tipo de carga y, en especial, del pago del quinto (del botín de guerra a la Corona), tal como lo está la milicia de la confraternidad de Jerusalén". La alusión a los templarios, contenida en las palabras milicia de la confraternidad de Jerusalén, suscita algunos problemas. El monarca busca para su cofradía aragonesa un paralelismo de prestigio con la institución de Jerusalén, por la que siente gran veneración. A primera vista parecería que Alfonso I había otorgado exención del quinto a los templarios en sus propios reinos, exención que toma como modelo para aplicarlo a Monreal. Sin embargo, tal como está redactado el texto, también cabe la

${ }^{5} \mathrm{Cf}$. Lema, Colección diplomática de Alfonso I de Aragón y Pamplona: 1104-1134, San Sebastián, 1990, documentos n. 203 y 241; Marquis d'ALBON, Cartulaire général de l'Ordre du Temple, n. XXXVIII, pp. 28-29; AHN, Códices, 595B, fol. 169v. En cuanto a la donación regia del 17-XII-1128, Pascual GaLINDO, en Sos en los siglos XI-XII, pp. 19-20, opina que la cesión al Templo debió de efectuarse poco después. Santos García LarragueTa, El Temple en Navarra, p. 638, cree que ambos actos, la donación real y la de D. Miro fueron casi coetáneas, pero ello no es seguro. Véase, asimismo, a G. MARTínEZ DíEZ, op. cit., p. 
lectura -sugerida por Gonzalo Martínez Díez y por la que nos inclinamos- de que la cofradía de Monreal gozaba de esta exención del mismo modo que la disfrutaban los templarios en el reino de Jerusalén. Por otro lado, la cronología no está clara. La carta episcopal carece de fecha. Con todo puede ser orientador que se considere a los templarios aún como una confraternidad o cofradía. Teniendo en cuenta que el Temple en sus orígenes era una cofradía y que no llegaría a institucionalizarse como orden hasta el concilio de Troyes, en 1129, la data más probable debería situarse en las gestiones que precedieron a dicho concilio a lo largo de 11271128 , años en que este grupo empezó a darse a conocer en Europa occidental. Cabe concluir que el rey pudo haber tenido entonces noticia de la existencia de esta agrupación, cuyos pasos suponemos que seguiría con interés. En efecto, las circunstancias se iban a mostrar pronto muy favorables al ulterior desarrollo de la institución ${ }^{6}$.

De hecho, los verdaderos orígenes de la implantación del Temple en los reinos de Aragón y de Pamplona - o, al menos, los primeros datos comprobados- arrancan de la época en que el rey Alfonso I asediaba - sin éxito aparente- la importante plaza costera de Bayona, en el país de Labourd (de octubre de 1130 al mismo mes de 1131). La campaña aragonesa al otro lado de los Pirineos coincide con un momento de rápida expansión del Temple por Occidente, una vez cerradas las sesiones del concilio de Troyes. Entre 1129 y 1131 el caballero Hugo Rigauld se desplaza por el S. de Francia y por tierras de Cataluña y Portugal, recabando ayudas para los templarios. No es aventurado suponer que él o alguno de sus colaboradores entablase contacto con el campamento real de Alfonso I en esta coyuntura. Por estas fechas, en julio de 1131, el conde barcelonés Ramón Berenguer III dictaba testamento y concedía a la orden su caballo Danc y sus armas, instrumentos y a la vez símbolos de su condición de caballero. No era poco. Añadió el castillo de Granyena, situado en la frontera con los musulmanes, con sus caballeros y la población campesina a él adscrita. Más aún, el propio conde se entregaba para militar en la orden como caballero. Ciertamente, dado que a nadie se le

${ }^{6}$ Cf. Gonzalo Martínez Díez, $O p$. cit., p. 28. El texto de Monreal, en Lema, $C . D$. Alfonso I, n. 141, también en LACARRA, Documentos para el estudio de la reconquista y repoblación de Valle del Ebro (Anubar, Zaragoza, 1982 y 1985), I, n. 173 de la $2^{a}$ edición. Sobre los orígenes y expansión inicial del Temple, cf. Malcolm BARBER, The new knighthood: a history of the Order ot the Temple, Cambridge University Press, 1995, pp. 8-37. 
ocultaba que le quedaban pocos día de vida, no era un compromiso realizable. Con todo, la orden ganaba un gran prestigio con el gesto de Ramón Berenguer. ¿Llegó a oídos del rey la noticia de esta última voluntad cuando iba a extender su propio testamento? Una conclusión se impone: ambos actos obedecían al mismo ambiente moral, cifrado en el espíritu cruzado, y a unas mismas necesidades de fortalecer y hacer avanzar la frontera con los musulmanes ${ }^{7}$.

Ahora bien, Alfonso I fue mucho más allá que el conde catalán. Su última voluntad, expresada públicamente en octubre de 1131, cuando estaba a punto de levantar el asedio de Bayona contemplaba al Temple entre sus destinatarios ${ }^{8}$. No cabe duda de que el rey sigue en cierto grado la misma pauta que el conde barcelonés, pues el monarca "Batallador" también dona a la orden su caballo y armas. La disposición más polémica es la que declara al Temple coheredero de sus reinos en plano de igualdad con otras dos instituciones hierosolimitanas: el Hospital de San Juan y el Santo Sepulcro ("totum tribuo et concedo Sepulcro Christi et Hospitali pauperum et Militie Templi Salomonis ut ipsi habeant et possideant per tres iustas et equales partes"). No se establece una porción específica de los reinos de Alfonso I que deba corresponder al Temple, sino que - así se desprende del documento- habrá de entenderse con los otros dos grandes herederos para obtener un tercio de este conjunto de territorios. Los templarios habrán de poseer con sus colegatarios el dominio (dominatum) sobre los reinos de Alfonso I, la autoridad sobre sus habitantes (principatum) y los bienes y rentas directamente adjudicados al mantenimiento del monarca y de sus familiares más directos (la honor real). Las potestades, caballeros e infanzones posesores de honores y tenencias regias quedan en una situación comprometida, en cuanto muera el soberano. El rey les da y les quita a un mismo tiempo. Se les reconoce en el testamento el disfrute vitalicio de sus posesiones, pero, una vez fallecidos, el Temple -con las otras dos instituciones copartícipes- estará facultado para redistribuirlas según crea conveniente: "ut post mortem meam illi qui per me tenent eas (honores), teneant in tota uita sua sicut per me et post

\footnotetext{
${ }^{7}$ D'AlBon, Cartulaire, I, pp. 25 y 28-29.

${ }^{8}$ Volvemos sobre el testamento en la parte final del presente trabajo donde exponemos una serie de consideraciones generales que deberían guiar un estudio específico y sistemático de sus contenidos.
} 
mortem illorum sint ab integro Sepulcri et Ospitalis et Templi Militie Salomonis et illius cui dare uoluerint eas"'

Estas enormes concesiones ${ }^{10}$ se efectúan sin que los templarios posean todavía una base patrimonial en los reinos de Alfonso I y, mucho menos, una red de encomiendas y casas dependientes. Incluso en Francia el grado de organización y afincamiento del Temple era todavía incipiente. Hay que entender que las concesiones a favor de Temple contenidas en esta última voluntad implican un programa de establecimiento de la orden. La lógica exigía, si los templarios habían de ser capaces de asumir tan graves responsabilidades, que Alfonso I hiciese todo lo posible, tanto por su propia iniciativa como estimulando a otros, por afianzar la presencia de la institución en sus reinos de Aragón y Pamplona y en las tierras adquiridas a costa de los musulmanes. ¿Hasta qué grado se cumplieron estos designios?

La documentación real es muy escasa. Las siguientes noticias alusivas a la voluntad de Alfonso I nos llevan a las postrimerías del reinado. El 29 de agosto de 1134 el monarca dio a conocer por medio de un mandato cómo había colocado bajo la dependencia del Temple a un poblador de Sos, Iñigo Fortuñones, probablemente un villano real. Sin lugar a dudas, debió de preceder al mandato una carta de donación de derechos a favor del Temple sobre el mencionado Iñigo. No se menciona de modo expreso, pero, según era habitual en este tipo de cesiones, la donación incluiría también a la mujer y a la prole del donado. Alfonso I ordenó a sus autoridades, en especial a Frontín, tal vez su merino o justicia en aquella zona de Aragón, que no consintieran lesiones contra los derechos del Temple en este particular. De este modo ningún otro señor podría exigir servicios al donado más que la orden. La pena estipulada contra los infractores es de 1000 sueldos. ¿Una verdadera multa o un simple recurso

${ }^{9}$ Cf. Lema, C.D. Alfonso I, n. 241.

${ }^{10}$ Sin llegar a los extremos de Alfonso I, García Ramírez, su sucesor en el trono pamplonés, mostró una extraordinaria generosidad con los templarios. Además de las seis donaciones que efectuó a su favor entre 1135 y 1148 (cf. Santos García LarRagueTa, El Temple en Navarra, pp. 641-642), al ingresar como cofrade en el Temple prometió post obitum sus caballos y armas. Asimismo, la orden había de beneficiarse del décimo del quinto real obtenido en cautivos y botín y durante un periodo de dos años, de la mitad de las tierras que el rey ganase a los musulmanes: "Garsias, // Pampilonensis rex, dat Milicie Templi de Iherusalem suam deciman de sua quinta et de hac festiuitate Omnium Sanctorum usque ad duos annos medietatem quod abuerit de terras sarracenorum et ad finem suum suas armas et totos quantos caballos abuerit" (AHN; Códices, 595 B, fol. 169 r.-v.). 
retórico que expresa, sin más, con una cifra simbólica, el interés regio en el asunto? De todos modos, es obvio que el monarca se preocupaba por crear un patrimonio y una incipiente base material para la orden en sus reinos. Sería revelador disponer de más documentos de este tipo que nos permitisen precisar mejor el alcance de las medidas reales a favor de los templarios ${ }^{11}$.

Lo que sí parecen seguras son las motivaciones personales de Alfonso I. El rey expidió su mandato desde Sariñena. Quebrantado moralmente después de la grave derrota que había sufrido a manos de los almorávides en las cercanías de Fraga (en el extremo S.E. de la provincia de Huesca, junto a Lérida) el 17 de julio de 1134, estaba también muy enfermo. Sintiendo la muerte próxima, en la misma Sariñena, el 4 de septiembre, renovó su testamento ${ }^{12}$. Repitió, para el Temple, las mismas disposiciones contenidas en el documento de 1131. Es muy probable que conciencia de la cercanía de su fin -fallecería unos días después, el 7 de septiembre- espolease al "Batallador" para acelerar la ejecución de sus designios a favor de la orden. En este ambiente sicológico hay que situar, por tanto, la expedición del mandato de agosto.

El balance que arrojan las cartas regias es pobre. Un testamento, su renovación y un mandato. Sumemos la ambigua alusión aparecida en el documento episcopal. Indican una voluntad real de actuar a favor de la orden y la admiración del monarca hacia la misma, pero no nos bastan para saber en qué grado se comprometió el rey en llevar sus designios a ejecución en una política de gobierno concreta. Sospechamos que el Temple se benefició de más donaciones y mandatos como el aludido en Sos, pero no podemos probarlo.

Las decisiones regias no lo son todo. Las simpatías hacia la naciente institución se extendieron rápidamente por el entorno real, entre los tenentes y caballeros que prestaban servicio al monarca, así como entre las familias nobiliarias. Serán, precisamente, estos apoyos sociales de la nobleza aragonesa, pamplonesa y, en cierta medida, alavesa, mantenidos bajo los mandatos posteriores de García Ramírez (1134-1150), Ramiro II (1134-1137) y Ramón Berenguer IV (1134-1162), los que

\footnotetext{
${ }^{1}$ Cf. LEMA, C. D. Alfonso I, n. 282

${ }^{12}$ Cf. Lema, C. D. Alfonso I, n. 284.
} 
hagan posible la presencia de la orden en tierras navarras y aragonesas hasta que se defina y asiente su red de encomiendas.

La primera donación particular a favor del Temple que cabe datar con cierta precisión tuvo lugar también durante el asedio de Bayona, quién sabe si antes del propio testamento regio. Diego Sánchez, yerno del señor alavés don Ladrón, concedió a la orden una renta anual de cinco sueldos y prometió para después de su muerte, su caballo y armas. Nos ha quedado el lacónico extracto del documento en una lista de cofrades del Temple ${ }^{13}$ : "Didag Sanz, gendre de Latron, V solidos annuatim et in fine suo armas et caballum. Et hoc stabilivit qum rex Adefonsus erat in Baiona"14. La iniciativa de Diego Sánchez - y las de otros magnates y caballeros que pudieron haber actuado simultáneamente- marca la pauta de la actitud de la nobleza ante la orden, que se respetará en los decenios posteriores. Se le otorga al Temple una renta, evaluada por lo general en sueldos o dineros y, casi siempre en el caso de los varones, el caballo y las armas. No se expresan las contraprestaciones, que se omitieron en el extracto (al copista templario, para decepción de los historiadores actuales, poco más le interesaba que idenficar al autor y el bien ofrecido). La contraprestación más importante es fácil de suponer: participar en los beneficios espirituales del Temple derivados de sus oraciones y actos de devoción como medio de alcanzar la salvación eterna. En segundo término, impulsa la acción de Diego Sánchez el deseo de conseguir prestigio vinculando su nombre y. el de su familia - no en vano se recuerda su parentesco político con el señor alavés- a una institución muy respetada que inicia entonces su despegue y que evoca la imagen, forzosamente idealizada y mitificada en estos confines de Occidente, del reino latino de Jerusalén. Tras todo ello, se halla el recuerdo de la Cruzada. No empleamos el verbo vincular por casualidad. Diego Sánchez, sin convertirse en templario stricto sensu, ha establecido una relación con la orden, está en su área de influencia. Es su benefactor económico y —cabe sospecharlo-

\footnotetext{
${ }^{13}$ Tres listas de cofrades, esto es, de laicos vinculados al Temple en los siglos XII y XIII fueron dadas a conocer por Agustín UBIETO en Cofrades navarros y aragoneses de la milicia del Temple, pp. 53-93, precedidas de un breve estudio cuantificativo. Nosotros hemos recurrido a la transcripción de las dos más antiguas, recogidas en el códice $595 \mathrm{~B}$ del AHN, ompletando con los datos que aporta Ubieto para la tercera.
}

${ }^{14}$ Cf. AHN, Códices, 595B, fol. 169 v. Edita Agustín UBieto, Cofrades, p. 56. 
su propagandista. Es un cofrade templario. No es el único, como vere$\operatorname{mos}^{15}$.

Mientras tanto, para ese año de 1134, se había formado un grupo estable de hermanos (fratres) del Temple en la plaza de Alagón, a orillas del Ebro, tal vez ya un conjunto de verdaderos miembros profesos en la orden. Habían acumulado la suficiente riqueza como para realizar ciertas transacciones de envergadura con la nobleza local. Más en concreto, Lope Cajal, sobrino del influyente magnate aragonés Fortún Garcés Cajal, obtuvo de ellos 90 cahíces de grano, de ellos 35 de trigo y el resto de cebada. Es evidente que no pagó en el momento, puesto que su poderoso tío hubo de quedar como fiador y responder, en consecuencia, con sus bienes de la transacción. Un dato significativo: Lope Cajal lleva a cabo la compra para abastecer a la cofradía asentada en Monreal. A la sazón era el tenente o senior gobernante de aquella plaza turolense por delegación del rey y de su tío. Es muy probable que ostentáse también la jefatura de esta cofradía aragonesa. Es reveladora está conexión, ya antes comentada, entre Monreal y el Temple.

Esta conexión aparece más clara si consideramos que Lope Cajal mismo se había entregado al Templo de Jerusalén, al que donó sus bienes raíces de Tudela, recibidos, a su vez, de Fortún Garcés: una casa con las tierras anejas, las yermas como las pobladas. De estos bienes el Temple había de recibir una renta anual de un morabetino mientras viviera el donante. A su óbito, según lo que parece una pauta establecida, la orden obtendría su caballo y armas ${ }^{16}$. ¿Cuál era el grado de vinculación de Lope Cajal con el Temple? No es, desde luego, un frater o miembro de sleno derecho de la orden. No tendría sentido que la orden vendiese grano a uno de sus miembros cargándolo con una deuda y obligándole a presentar garantes. Su entrega al Temple hay que considerarla, más bien, como la de un cofrade. Es la suya, de todos modos, una vinculación

\footnotetext{
${ }^{15}$ Diego Sánchez parece ser el tenente de Mena por Alfonso I. El documento real alusivo a la tenencia -LEMA, C.D. Alfonso I, n. 226, lo cita en la lista de autoridades del escatocolo poco después de Ladrón, señor de Alava, su suegro, de ser válida nuestra asociación: "Latron in Alaua. Petrus Martineç in Çastella. Didaco Sangeç in Mena".

${ }^{16} \mathrm{Cf}$. LaCARra, Documentos, n. 249: "Ego Lop Kaixal, in mea vita et in mea salute, ascendo et dono meum corpus et meam animam ad illam caualleriam de Templo de Iherusalem, et dono illam meam casam de Tutela cum tota sua hereditate herema et populata (...) ad illam cavallariam de Templo Salomonis, ut annuatim habeant de ea in tota mea vita unum morabetinum, et ad meum obitum, caballum et meas armas".
} 
relevante, pues pertenece a una de las familias aragonesas mejor situadas en la corte regia y más favorecida en el reparto de tenencias y señoríos por el monarca. A través de Lope, de su militancia simultánea en dos cofradías se forja una relación con el grupo de combatientes de Monreal. La muerte de Lope Cajal en la desastrosa batalla de Fraga, librada el 17 de julio de 1134 por la hueste de Alfonso I contra los almorávides, ejemplificaría y popularizaría a los ojos de sus contemporáneos la imagen del caballero que sacrifica su vida poniéndola al servicio de un ideal, tan en boga en ese momento, a la vez bélico y religioso ${ }^{17}$.

Fortún Garcés Cajal, el gran mentor de Lope, no dudó, por su parte, en apoyar al Temple. Su testamento de octubre de 1133 legaba al Temple sus heredades de Tudela, Fontellas, Castellone, Morzano y Soiset, más un molino y un soto en Alcaten. Es llamativa la atención que el magnate aragonés presta a las órdenes e instituciones eclesiales del reino de Jerusalén, puesto que los otros dos beneficiarios de su última voluntad son el Hospital y la iglesia de Santa María de Belén ${ }^{18}$.

En las listas de cofrades templarios consta un Cajal que debía cierta cantidad de sueldos a la orden: Caissals $F$. ex centum solidos d'un son parent ${ }^{19}$. El texto es muy ambiguo y no identifica claramente a qué miembro de la familia se refiere ${ }^{20}$. Ahora bien, considerando que a continuación se indica que su madre había de entregar una loriga a la orden (Et máter eius debet loricam), al menos, podemos descartar a Fortún Garcés, por aquellas fechas demasiado avanzado en edad para que aún sobreviviese su madre ${ }^{21}$. Ha de tratarse de García Cajal, hijo de Fortún, fallecido en 1133, tal vez durante las operaciones contra los almorávides de Mequinenza, o de su sobrino Lope Cajal, muerto en combate en 1134. Si la loriga es la de alguno de ambos, deberá sobreentenderse que la madre estaba obligada a donar más que la pieza en sí, su valor en dinero

\footnotetext{
${ }^{17}$ LACARRA, Documentos, n. 249.

${ }^{18}$ LACARRA, Documentos, n. 226. Sobre Fortún Garcés y sus redes de tenencias, cf. LEMA, Instituciones politicas del reinado de Alfonso I "el Batallador", rey de Aragón y Pamplona (1104-1134), Servicio Editorial de la Universidad del País Vasco, Bilbao,1997, pp. $155-156$.

${ }^{19} \mathrm{Cf}$. AHN, $595 \mathrm{~B}$, fol. $168 \mathrm{v}$.

${ }^{20}$ Tampoco si debía entregar los cien sueldos íntegros o una parte de ellos; desconocemos el papel jugado por el pariente que se menciona en el extracto.

${ }^{21}$ Fortún Garcés venía ejerciendo funciones de tenente desde 1113 como mínimo.
} 
o especie, puesto que lo más probable es que el equipo de los dos combatientes se hubiese perdido en la campaña.

Otros seniores aragoneses favorecieron a la orden en 1133 y 1134. En un momento indeterminado entre esos dos años, Lope Garcés "el Peregrino", tenente de Alagón y El Castellar, en tierras del Ebro, extendió su testamento. Determinó, bajo diversas condiciones, que la mitad de sus bienes muebles y la mitad de sus bienes raíces se repartieran entre el obispado de Zaragoza, el Hospital de Jerusalén y, finalmente, el Temple. De sus bienes muebles se remarcan el caballo y las armas. Dadas las tendencias comunes en la época, es muy probable que los templarios hubiesen sido sus destinatarios preferentes ${ }^{22}$. El apodo mismo de "Peregrino", alusivo a una posible estancia en los santuarios del reino de Jerusalén, indica una especial predisposición o sensiblidad hacia los valores de la cruzada.

Aunque, a diferencia de Lope Cajal, no consta una vinculación de cofrade templario en los casos de Fortún Garcés y de Lope Garcés, ambos manifiestan como característica común una decidida voluntad de favorecer a la orden. Asimismo, consideramos significativo que los tres hubiesen formado parte del grupo de infanzones pamploneses, aragoneses $\mathrm{y}$ francos que juraron el testamento regio de 1131. A los tres les inspira un mismo ambiente de exaltación bélica y militar, unos mismos valores y un mismo ejemplo ${ }^{23}$.

Existe, pues, una voluntad regia de favorecer al Temple y preciosos indicios que nos hablan de apoyos nobiliarios. Pero éstos son mucho más amplios.

\section{UNA PODEROSA RED DE COFRADES}

En efecto, los últimos cinco años del reinado y los decenios inmediatamente posteriores, presencian el despegue y desarrollo de una verdadera red de colaboradores nobiliarios extendida por Pamplona y Aragón. Es también el periodo en que Bernardo de Claraval difunde con su De laude novae militiae una imagen embellecida de la naciente orden, justifi-

\footnotetext{
${ }^{22}$ LACARRA, Documentos, n. 230.

${ }^{23}$ LeMA, C. D. Alfonso I, n. 241.
} 
cando, con argumentos muy complejos y retóricos el arduo problema de combinar el ideal monástico con el caballeresco y militar. Se constituye una gran asociación de magnates vinculados al Temple, que, como mínimo, perdurará hasta comienzos del siglo XIII. Parece innegable que esta cofradía estaba en estrecha comunicación y relación con otras cofradías aragonesas de orientación semejante, en especial con la de Monreal. En el análisis de este importante grupo de presión nobiliario, del que nos consta la existencia de 526 miembros, nosotros, por nuestra parte, nos limitaremos a las figuras que estuvieron más relacionadas con el rey Alfonso I y a algunos descendientes por vía familiar y hombres dependientes de estos cofrades. A este respecto, hemos seleccionados 52 casos $^{24}$.

El fenómeno no se limitaba a Navarra y Aragón. Era general. De hecho, la regla templaria desde muy pronto admitió que los laicos se asociasen a la orden, beneficiándose, como cofrades de sus beneficios espirituales y oraciones, bajo la condición de donar bienes para su muerte, llevar una vida honorable y, en general, procurar favorecer a la orden. Junto a esta cofradía de carácter general, se organizaron otras de alcance local, como la que tenía por sede Novillas ${ }^{25}$. Las tierras catalanas conocen algunos casos notorios, como el de Gardeny, cuya cofradía templaria contaba, al menos, con 93 asociados conocidos en un periodo que se extiende desde la fundación de la encomienda (1149-1156) hasta $1204^{26}$.

Lo habitual es que uno de estos magnates señale el modelo y pauta a seguir a sus familiares y vasallos. La figura de Ladrón, el señor alavés desde 1130 , es un claro paradigma ${ }^{27}$. Sigue al rey al asedio de

\footnotetext{
${ }^{24}$ Para una visión de conjunto, cf. el artículo de Agustín UBIETO mencionado en las notas 1 y 13.

${ }^{25}$ Cf. Agustín UBIETO, Cofrades, pp. 45-48. Sobre la encomienda de Novillas se dispone de los trabajos de Ana Isabel LAPENA PAUL, Formación y explotación de la encomienda templaria de Novillas en el siglo XII, en "Homenaje a don José María Lacarra de Miguel en su jubilación del profesorado", V, Zaragoza, 1977, pp. 79-99.; y La encomienda de la orden del Temple en Novillas (siglo XII), "Cuadernos de Estudios Borjanos", 7 (1979), pp. 95-169.

${ }^{26} \mathrm{Cf}$. SANS I TRAvÉ, Els templers catalans, pp. 140-141.

${ }^{27}$ Ladrón está presente en la comitiva real desde $1118-1119$, como mínimo, pues participó en el asedio de Zaragoza. Implicado en una revuelta dirigida contra el rey por Diego López de Haro en 1124, logra reconciliarse con el soberano. Es señor de Alava desde 1130 (cf. LEMA, C. D. Alfonso I n. 226), de Falces hacia 1130-1133 (cf. LEMA, C.D. Alfonso I, n. 204) y de Haro en 1133 (LEMA, C.D. Alfonso I, n. 274). Una documentada visión de conjunto sobre su figura histórica puede consultarse en María R. AYERBE, Historia del Condado de Oñate y Señorío de los Guevara (s. XI-XVI), S. Sebastián, 1984, pp. 69-85. Resulta extraño que en el testamento de 1131, a Ladrón se lo mencione con el título de
} 
Bayona y es uno de los cojuradores. En fecha indeterminada, probablemente aún en vida de Alfonso I, se integra en la cofradía ofreciendo una renta vitalicia de veinte sueldos anuales y - como resulta casi inevitablesu caballo y armas para su muerte. De faltar la montura, debía suplirse con su precio equivalente en bienes muebles o raíces: "Latron similiter annuatim debet dare ad festum Natalis XX solç et in fine cauallum et armas. Et si non habuerit cauallo, dent precium de auere uel de hereditate"28.

El ejemplo de Ladrón es seguido por su hijo Vela, continuador de la línea principal de la familia, que se integra en la cofradía en similiares términos $^{29}$ (renta vitalicia y para después del óbito, cabalgadura y equipo militar). La tendencia se transmite de generación en generación, puesto que en el último cuarto del siglo XII un hijo de Vela, Pedro Vélez, adoptará la misma decisión ${ }^{30}$. Del mismo modo actuará un Fortún López, nieto o sobrino del señor de $\mathrm{Alava}^{31}$. Las implicaciones familiares no acaban aquí. Una hija de Ladrón, cuyo nombre no se precisa, casada con Ramiro Garcés, del linaje real pamplonés, se incorpora como cofrade aportando, en una donación típica de la rama femenina de estos vinculados, una mula y un manto o mantel ${ }^{32}$.

Las ramificaciones templarias se extienden por vía del parentesco político. Ladrón es imitado por tres de sus yernos. Uno de ellos es el citado magnate y miembro de la familia real navarra Ramiro Garcés ${ }^{33}$. No hace falta volver sobre el caso de Diego Sánchez, tal vez el señor de Mena homónimo, el primer cofrade templario que conocemos. La tercera

conde o comes, cuando parece que no lo consiguiò sino después de fallecer Alfonso I, por prestar apoyo a García Ramírez (cf. AYERBE, op. cit., pp. 74-76, que extracta las crónicas alusivas a las circunstancias históricas de la obtención del título condal). ¿Un lapsus del copista del testamento o un leve indicio de irregularidad?

${ }^{28} \mathrm{AHN}$, Códices, 595B, fol. $166 \mathrm{r}$.

${ }^{29}$ AHN, Códices, 595B, fol. 166 r.: "Beila, filius Latronis, debet dare I morabitinum ad Sanctum Michaelem et ad mortem equum cum armis".

${ }^{30} \mathrm{Cf}$. Agustín UBieto, Cofrades, p. 72: "Petro Veleç, filius de Vela Latron, annuatim suam caritatem; in fine suo cavallo et suas armas".

${ }^{31}$ AHN, Códices, 595B, fol. 169 v.: "Fortun Lopiz, nepos de Latron, caballum et armas".

${ }^{32}$ AHN, Agustín UBIETO, Cofrades, p. 73: "Filia comitis Latronis, mulier Remir Garcez, in suo fine suam mulam et suum mantellum".

${ }^{33} \mathrm{AHN}$, Códices, 595B, fol. 181 v.: "Raimir Garceç, lo cosin del rei, suo cauallo et suas armas a sua fine". 
conexión se establece con la casa de los Mendoza, más concretamente, con el yerno Lope López de Mendoza, otro cofrade más ${ }^{34}$.

Fortún Aznárez de Medina, señor tenente de Tarazona (desde 1124) y Filera (en 1132) (35 $^{35}$ presenta un comportamiento muy similar al de Ladrón. Al igual que el señor alavés, es uno de los juradores del testamento de 1131. No consta con seguridad su ingreso en la cofradía, pero sí los de sus allegados: su mujer Taresa, con entrega de mula y paños, un hermano, Tarín, con donación de caballo y equipo militar, loriga inclusive, y un nieto, Guillermo del Castillo ${ }^{36}$, en términos similares. Las redes de dependencia feudal se manifiestan en el ingreso de Guillermo de Asín, uno de los caballeros del senior tirasonense ${ }^{37}$.

Pedro Tizón gobernó las plazas de Aibar (1125-1133), Estella (1124-1134), Cervera de Río Alhama (1129-1134) y Barbastro (11161134), entre otras, bajo el mandato de Alfonso $\mathrm{I}^{38}$. Consta su afiliación a la cofradía, a la que se comprometió a ceder el diezmo de sus animales de carga (omnium suorum iumentorum deciman tribuit), mientras que uno de sus hijos, Jimeno Pérez, ofreció una renta anual e hizo la consabida promesa de ceder caballo y armas ${ }^{39}$.

Pedro Momez ejerció el cargo de tenente en Marañón ${ }^{40}$ (11161123) y Arróniz ${ }^{41}$ (1131) e intervino en la repoblación de la primera de

${ }^{34}$ AHN, Códices, 595B, fol. 166 v. y 168 v.: "Lope Lopiç de Mendosa, ierno de Ladron, XXX solç et ad suo fine cauallum et armas et si non habuerit cauallo, dent de sua hereditate uel de suo auere D solç".

${ }^{35}$ Cf. LEMA, C.D. Alfonso I, n. 133 y 250.

${ }^{36}$ Agustín UBIETO, Cofrades, p. 79: "Domna Taresa, mulier de senior Fertung Acenariz de Tarassona, sua mula et suum meliorem mantellum (...) Guillem de Castillo, neto de Fotun Acenar de Tarazona, donat a sua fine suo cavallo et suas armas Deo et fratribus Templi Salomonis". También, AHN, Códices, 595B, fol. 179 v.: "Tarin, germano de Fortun Acenariz, ad suum obitum equum suum et armas suas et si non habuerit equum, una de suis melior bestiis quam habuerit cum sua lorica et suis armis".

${ }^{37}$ Cf. AHN, Códices, 595B, fol. 179 v.-180 r.: "Guilem de Asine, caballero de Fertun Acenariç, per unoquoque anno VI diners et ad sua morte // suo cauallo et suas armas"

${ }^{38}$ Para Aibar, cf. MARTín DUQUE, Documentación medieval de Leire (siglos IX al XII), Pamplona, 1983, n. 273 y AHN, Códices, 1296 B, fol. 37; para Estella, LEMA, C. D. Alfonso I, n. 125 y 274; para Cervera, LEMA, C.D., n. 218, Agustín UBIETO, Los tenentes en Aragón y Navarra en los siglos XI y XII, Valencia, 1973, p. 265; para Barbastro, LEMA, C. D. Alfonso I, n. 75 y 279.

${ }^{39} \mathrm{Cf}$. AHN, Códices 595 B, fol. 177 r. y Agustín UBieto, Los Cofrades, p. 79.

${ }^{40}$ LEMA, C.D., n. 68, 123.

${ }^{41}$ LEMA, C.D., n. 245. 
estas plazas. Al hacerse cofrade prometió ceder su equipo militar -se supone que post obitum- y ofreció ciertos donativos. Su voluntad no debió de cumplirse de manera automática, puesto que el redactor de las listas de cofrades recordaba que su viuda, Jordana, aún debía veintitrés morabetinos en que se apreciaba una loriga de su marido, y algunas otras cantidades. Jordana, por su parte, había de entregar un potro anualmente $\mathrm{y}$, después de su óbito, su cabalgadura y su mejor manto o mantel ${ }^{42}$. Miguel, hijo del matrimonio, y un hermano de nombre desconocido continuaron esta tradición templaria ${ }^{43}$.

Fortún López de Soria fue uno de los tenentes más importantes del reinado de Alfonso I. Hacia 1127 dominaba conjuntamente en Mendigorría, Milagro y Ujué, en tierras pamplonesas, y en Burgos, San Esteban de Gormaz, Soria, Yanguas y San Pedro Manrique, en Castilla ${ }^{44}$. Tiene en común con todos los demás magnates mencionados su presencia en la jura masiva del testamento de Alfonso I. Por diversas referencias, conocemos que dispuso, al entrar como cofrade, la donación típica de cabalgadura y armas para su muerte y una renta vitalicia, cuya cuantía ignoramos. Todo un conjunto de familiares y dependientes jerárquicos se suman a su iniciativa. En primer lugar su mujer Sancha, a quien la vinculación templaria le supone el pago de una renta anual vitalicia y la entrega para su óbito de su mejor montura con silla y freno ${ }^{45}$. La vinculación templaria llega en un momento indeterminado, tal vez ya a mediados del siglo XII, al alcaide soriano Fortún Garcés y a los familiares de este último. Por un lado, nos referimos a su esposa Urraca, que era, a la vez, hermana del

${ }^{42} \mathrm{Cf}$. AHN, Códices, 595 B, fol. 168 v.: "Iordana, mulier de Petro Momet, debet XXIII morabetinos d'una lorica et ipsa meminit se elemosina primo marito"; fol. 169 r.: "Ego, Iordana, mulier de Petro Momet, dono annuatim uno poltro de equas et in fine meo equitaturam et mantellum meliorem".

${ }^{43} \mathrm{AHN}$, Códices, $595 \mathrm{~B}$, fol.: "Et meus filius Michael suam caritatem annuatim et in finem suum caballum et armas. Et alius filius similiter et si non abebant suas meliores duas bestias quas abebant"; asimismo, fol. 173 r.: "Don Michael, filio de Petro Momez, et suo germano lures cauallos et lures armas totas in lure fine. Et si non habuerint, meliorem bestiam quam abuerint. Et de lures equis tota illa decima".

${ }^{44} \mathrm{Cf}$. LEMA, Instituciones, p. 163.

${ }^{45}$ Cf. AHN, Códices, 595B. fol. 178 r.: "Ego Sancia, uxor Fertun Lobeç de Soria, promito animo fidelissime, dono prefate confratrie in tota uita mea singulis annis tantum caritatis quantum uir meus prefatus constituit pro sua anima annuatim dare et in obitu meo meam equitaturam sellatam et frenatam et meliorem mantellum" (178 r.). También Agustín UBIETO, Cofrades, p. 69: "Fertun Lopiz de Soria ad sua fine suo cavallo et suas armas". 
tenente soriano, y a otro hermano, García Garcés de Funes ${ }^{46}$. Por otro, encontramos a un hijo de dicho alcaide, Pedro Fortuñones ${ }^{47}$. Con este grupo de familiares y dependientes de Fortún López podrían guardar relación cierta María, "la del castillo de Soria", y su hija Juliana que ofrecieron a la orden una renta de doce sueldos anuales ${ }^{48}$.

Estas conexiones de cofrades por vía familiar y vasallática se repiten en otros personajes del entorno real. En unos casos constan; en otros, la lógica nos autoriza a sospecharlas: en un Alamán de Luna, miembro de la comitiva real de Alfonso I, y su esposa, doña Amabilia, en el caballero franco Gassion, tenente de Belorado (1120-1131) y su hijo Aznar, en los seniores tenentes Castán de Biel, Fortún Aznárez de Berlanga, Fortún Galíndez de Alfajarín, Ramón de Cortes y sus respectivas mujeres, en Pedro Guillermo de la Laguna y Lope, uno de sus descendientes y otros muchos.

Detrás de todo, siempre como punto de arranque, se perciben las consecuencias del testamento real de 1131, pues una treintena de los casos escogidos corresponden a juradores o a parientes de juradores de la última voluntad del monarca "Batallador".

\section{CONCLUSIONES Y REPLANTEAMIENTO DE UN VIEJO PROBLEMA}

Recapitulando los datos arriba comentados, es evidente el gran éxito que en los medios nobiliarios navarros y aragoneses tuvo la cofradía templaria. Su nacimiento se sitúa en a la época del asedio de Bayona. Las funciones del grupo para los intereses de la orden son fáciles de comprender. Es una manera de obtener apoyos sociales e influencia y de hacer propaganda del Temple. El beneficio material no resulta desdeñable. En efecto, los cofrades dejan o prometen dejar valiosos bienes muebles en el momento de su ingreso. En el caso de los varones, caballos, con sus

\footnotetext{
${ }^{46}$ Cf. AHN; Códices, 595 B, fol. 178 v.-179 r.: "Ego, Urracha, uxor Fertun Garceç, alcait de Soria sub manu fratris, prefati Fertun Lobez, communi fidelium fidei me commitens et confidens saluari,dono eidem confratrie Sancti Templi omni anno II". morabitinos". También, Agustín UBIETO, Cofrades, p. 73.

${ }^{47} \mathrm{AHN}$, Códices $595 \mathrm{~B}$, fol. $180 \mathrm{r}$.

${ }^{48}$ Cf. AHN, Côdices, 595 B, fol. 175 v. -176 r.: "Ego Maria de illo castello de Soria et mea filia Iuliana anima de Michael Momeç XII dineros unoquoque anno".
} 
arreos, y armas. Las mujeres aportan sus monturas y paños de valor.Servirían, en parte, para el propio equipamiento militar de los miembros de la orden y la otra parte para la obtención de recursos mediante su venta. Con estos bienes se incluyen rentas vitalicias y, más rara vez, donaciones de heredades. El ejemplo de estos cofrades sirve de estímulo a otros miembros de la nobleza para efectuar donaciones al Temple.

Pero más que por la cuantía de las ayudas aportadas interesa subrayar el momento en que éstas se producen. Hasta mediados del siglo XII, sobre todo, hasta el acuerdo con Ramón Berenguer IV de 1143, que regulaba las relaciones de la orden con la Corona aragonesa, los templarios no empiezan a desarrollar su red de encomiendas y a afincar su estructura organizativa. Teniendo en cuenta que una parte sustancial de las aportaciones de los cofrades son del periodo 1130-1160, se comprende el valor inapreciable que esta asociación revistió en la fase inicial y crítica de introducción de la orden, mientras sentaba las bases de su patrimonio. Es lícito sospechar que si el Temple ejerció en esos decenios alguna influencia en Navarra y Aragón, dependió para ello de su red de asociados nobiliarios, cuando su propio patrimonio aún era débil.

Para los cofrades, el beneficio derivado de su vinculación al Temple es el prestigio, que contribuye a consolidar su preheminencia en la sociedad aragonesa y pamplonesa de su época. Buscando razones más personales, tal vez, para muchos de los juradores era un medio de tranquilizar sus conciencias por el incumplimiento del testamento de 1131. En el caso de los magnates se ha probado la difusión familiar de la participación en la cofradía, extendida a esposas, hermanos, hijos, nietos, sobrinos y yernos. Se refuerzan, además, los vínculos de dependencia vasallática con los caballeros vinculados a los tenentes, puesto que se sienten obligados -o son obligados- a seguir el modelo y ejemplo de sus señores.

En último término, sigue pendiente el mayor problema, al que está conectada la introducción de los institutos religiosos de Tierra Santa en Aragón y Pamplona. El sentido del testamento de Alfonso I se halla lejos de haberse aclarado. Un intento sistemático para proponer una explicación satisfactoria exigiría una monografía específica, pues obligaría a recapitular la trayectoria de todo el reinado. De todos modos, sí sería conveniente señalar algunas claves que deberían tenerse en cuenta en esta labor.

La cuestión inicial por dilucidar radicaría en determinar si verdaderamente Alfonso I pretendía que su última voluntad se pusiera en prácti- 
ca en los términos expresados en el documento o si se trataba de un ardid para asegurar la herencia de sus reinos en Ramiro II, como sugirió Elena Lourie. Esta explicación, muy problemática en su conclusión final, pero que aporta en su argumentación algunas ideas de interés, generó un debate con A. J. Forey. Sus críticas apuntan a la imagen de un monarca de espíritu cruzado tan ciegamente preocupado por la salvación de su alma y por favorecer a las órdenes del reino de Jerusalén que estaba dispuesto a desdeñar las recomendaciones del realismo político ${ }^{49}$.

El propio discurso del testamento debería ser objeto de más atención, en especial las consideraciones del preámbulo -elemento diplomático muy extraño en las cartas aragonesas de esta época- sobre la caducidad de la vida y buscar sus conexiones y precedentes con las corrientes de pensamiento imperantes en su época y las tradiciones literarias vigentes. En las cláusulas del dispositivo, merecería la pena dedicar un tiempo a definir con más precisión la terminología política utilizada en esta carta y valorar en su justa medida el sentido de términos como dominatum y principatum. Nadie parece haberse percatado de la división y jerarquización de la sociedad que se sugiere en la cláusula de entrega de sus reinos a las órdenes, que arranca con una distinción entre clérigos y laicos y una enumeración muy detallada de todos los grupos sociales que entran en cada una de

\footnotetext{
${ }^{49}$ Elena LouRIE abrió el debate con su ya famoso The Will of Alfonso I "El Batallador", King of Aragon and Navarre: a Reassesment, "Speculum: a Journal of Medieval Studies", L/4 (1975), pp. 635-651. Suponía que Alfonso I pretendía dejar sus reinos a Ramiro, su hermano menor, y que el testamento, que en las intenciones del monarca no debía cumplirse tal como estaba redactado, era el medio ideal para paralizar la intromisión de Alfonso VII de Castilla, apoyado por el papa Inocencio II, en sus reclamaciones sobre las tierras navarras y aragonesas. La respuesta de A. J. FoREY, aunque se hizo esperar, fue especialmente crítica: The Will of Alfonso I of Aragon and Navarre, "Durham University Journal", 73 (1980-81), pp. 59-65. LOURIE, dándose por aludida, respondió con su The Will of Alfonso I of Aragon and Navarre: A Reply to Dr. Forey, "Durham University Journal", 77/2 (1984-85), pp. 165172. FOREY supone que el rey "Batallador" se proponía cumplir el testamento tal como lo expidió, llevado por un absoluto desprecio hacia los intereses de sus reinos y de sus súbditos. Más aún, lo subordinó todo de la manera más extremista al fomento los intereses de las instituciones de Tierra Santa y del reino de Jerusalén. Malcolm BARBER, en su The new knighthood, pp. 30-31, da a entender que se inclina por la postura de FOREY, argumentando que el discurso del documento es demasiado claro para abrigar sospechas de ambigüedad o engaño, que el rey ya había manifestado su vocación de cruzado mediante la fundación de cofradías militares, que Inocencio II no dudó de que era la genuina voluntad del monarca y que la carta refleja las mentalidades contemporáneas de las que sólo se aparta en el grado de entusiasmo.
} 
estas dos categorías ${ }^{50}$. Ciertamente, hay que ser cautos. No se habla en la enumeración ni de órdenes ni de funciones, pero uno se siente tentado de comparar esta lista con los resultados de las reflexiones, ya clásicas, de un Duby sobre los tres órdenes - aunque no es, en principio, el mismo esquema- y el imaginario del feudalismo ${ }^{51}$.

No está claro qué servicio pretendía Alfonso I de las tres grandes instituciones colegatarias, de las que sólo una, el Temple, es, sin lugar a dudas, una orden militar en 1131. No es evidente el carácter militar del Santo Sepulcro y podemos preguntarnos si el Hospital de Jerusalén, una orden asistencial en su origen, se había militarizado ya en la época del testamento ${ }^{52}$. Además de la ayuda militar, indudable en el Temple, convendría debatir si existía también el deseo de favorecer el desarrollo y afianzamiento de las grandes rutas de peregrinación -y de circulación comercial- que cruzaban por sus reinos, en especial el Camino de Santiago.

Con las órdenes del reino de Jerusalén, aparecen poderosas instituciones eclesiales pamplonesas, aragonesas y castellanas entre los beneficiarios de los legados (la catedral de Pamplona, el monasterio de Leire, San Juan de la Peña, San Pedro de Siresa, Santa María de Nájera, San Millán de La Cogolla, San Salvador de Oviedo, Santo Domingo de Silos y la sede compostelana). Sus legados son muy sustanciales y abarcan castillos y poblaciones enteras. ¿Hicieron algún esfuerzo por reivindicar

\footnotetext{
${ }^{50}$ Cf. LEMA, C.D. Alfonso I, n. 241: "His tribus totum regnum meum concedo, dominatum quoque quem habeo in tota terra regni mei, principatum quoque et ius quod habeo in omnibus hominibus terre mee tam in clericis quam in laicis, episcopis, abbatibus, canonicis, monacis, obtimatibus, militibus, burgensibus, rusticis, mercatoribus, viris et mulieribus, pusillis et magnis, diuitibus et pauperibus, iudeis et sarracenis, cum tali lege et consuetudine quale pater meus et ego hactenus habuimus et habere debemus". Causa cierta perplejidad que se cite antes a los "rústicos" que a los "mercaderes", a los que se diferencia de los "burgueses".

${ }^{51} \mathrm{Cf}$. el ya clásico de Georges DUBY, Les trois ordres ou l'imaginaire du féodalisme, en la recopilación de obras Féodalité, Editions Gallimard, 1994 (1978),., pp. 457-825. Hay traducción en Los tres órdenes y lo imaginario del feudalismo, Argot, Barcelona, 1983.

${ }^{52}$ Sería más propio considerar el Hospital no tanto como una orden militar sino más bien como una orden militarizada parcialmente. FOREY se inclina por situar el origen de la militarización en dos momentos distintos: uno en Siria y Palestina, a mediados de la década de los treinta del siglo XII y otro en España, a finales de la década de los cuarenta de la esa centuria (The Militarisation of the Hospital of Saint-John, "Studia Monastica", 26 (1984), pp. 75-89. Por lo que toca a Aragón, María Luisa LEDESMA RUBIO venía a coincidir con estas apreciaciones en sus Notas sobre la actividad militar de los hospitalarios, "Príncipe de Viana", 25 (1964), pp. 51-56.
} 
sus derechos tras la muerte de Alfonso I? ¿Era posible armonizar estas donaciones con los intereses de las tres órdenes de Tierra Santa en caso de que se hubiera llevado a cabo el testamento? ¿Por qué estas elecciones y no otras? Alfonso I tenía especial vinculación personal con San Pedro de Siresa, donde se había educado en la infancia, y demostró una notable atención durante su reinado a San Juan de la Peña. No parece en cambio que favoreciese demasiado a Leire. Sus relaciones con el obispo Gelmírez de Compostela fueron muy conflictivas. Es sorprendente que omita toda alusión a la abadía de Montearagón, una de las favoritas de la monarquía aragonesa, y a los obispados de Jaca-Huesca, Zaragoza, Barbastro y Tarazona.

Las relaciones del monarca con la nobleza de sus reinos se basaba en la distribución de honores y tenencias entre sus magnates, caballeros e infanzones. El testamento les concede el disfrute de estas concesiones mientras vivan. El fallecimiento de los titulares de honores facultará a las tres grandes órdenes beneficiarias para redistribuirlas a su conveniencia. El sistema, en cierta medida, seguirá funcionando, pues el rey no prevé una organización política ni una relación con los nobles sin régimen de honores y tenencias. No obstante, después de la muerte del rey, los nobles aragoneses y pamploneses se encontrarán con unos inesperados señores eclesiásticos por encima de ellos. ¿Cuáles eran los cálculos de los señores juradores del testamento ante tales perspectivas? ¿Tuvo que forzarles el monarca a prestar un juramento tan poco coincidente con sus intereses? ¿Habría, al menos, una minoría, que plenamente identificada con los ideales del monarca, aceptaba el contenido de la última voluntad aun por encima de sus conveniencias materiales, familiares y patrimoniales inmediatas? En último término, toda explicación de este punto habrá de conectarse con la evolución general del feudalismo en Navarra y Aragón en esta época.

No se ha observado que el testamento implica una reordenación territorial de los reinos del "Batallador". Las tres órdenes se habrán de repartir estos reinos en tres partes equivalentes. No se mencionan como objeto expreso de este reparto las unidades políticas existentes: el reino de Pamplona, con sus ampliaciones riojanas y castellanas (tal vez incluso sea temerario suponer que Alfonso I considerase que la actual Rioja había de formar parte del reino de Pamplona), de Aragón, con Sobrarbe y Ribagorza, y las tierras ganadas en el Regnum Caesaraugustanum. El testamento no supone ningún respeto a estas unidades. De haberse llevado a 
cabo en el sentido más estricto y literal del término, podría haberse alterado por completo la organización política en el N.E. de España. ¿Habría surgido un antecedente en el Valle del Ebro de lo que luego serían los estados teutónicos en el área báltica?

Una interpretación global del testamento habría de integrar, jerarquizándolos de manera lógica, estos problemas. Quién sabe si bajo estos legados no se esconde un proyecto político muy elaborado ideológicamente por alguno de los clérigos de la corte real que daría sentido a todo este conjunto. Ahí está el reto.

\section{RÉSUMÉ}

L'implantation de l'Ordre du Temple dans les royaumes d'Aragon et de Navarre s'amorça lors des dernières années du règne d'Alphonse $\mathrm{I}^{\mathrm{er}}$, notamment après que celui-ci eut fait son testament de Bayonne (octobre 1131). Or, si les successeurs s'Alphonse Ir -García Ramírez en Navarre, Ramon Berenguer IV en Aragon- continuèrent à offrir leur soutien à l'ordre, l'enracinement du Temple dans ces territoires n'en doit pas moins à l'initiative privée de nombre de membres de la noblesse locale. Engagés dans des confréries liées à l'ordre, ceux-ci agirent en sympathisants et propagandistes et attirèrent des donations qui aidèrent à poser les bases du temporel des templiers dans la région.

\section{SUMMARY}

The order of the Temple was introduced in kingdoms of Aragón and Pamplona during the final years of the rule of Alfonso I, and especially after the issue of his controversial will in Bayonne (October 1131). However, during the early years of the consolidation of the order in these territories, as important as the power from the public authorities lead by García Ramírez in Navarra and Ramon Berenguer IV in Aragon was the role played by a large number of local noblemen grouped in brotherhoods of laymen associated with the Temple. Thanks to the influence of these noblemen, the order had a network of sympathisers and supporters which attracted donations for the institution and helped to consolidate its economic base. 